\title{
PERAN MEDIASI KEPUASAN PELANGGAN PADA PENGARUH E-SERVICE QUALITY, PERSEPSI HARGA, DAN PROMOSI PENJUALAN TERHADAP LOYALITAS PELANGGAN
}

\author{
Risa Septiani \\ Nurhadi \\ Universitas Negeri Yogyakarta \\ nurhadi.fe@uny.ac.id
}

\begin{abstract}
This study aim was to determine the effect of e-service quality, price perception, and sales promotion on customer loyalty through customer satisfaction on Gojek customers in Yogyakarta. This research is a quantitative study with survey method. The population in this study were Gojek customers in Yogyakarta. The sampling technique used was purposive sampling, with a total sample of 235 respondents. The technique of collecting data used an online questionnaire that has been tested for validity and reliability. The data analysis technique used to test the hypothesis was bootstrapping method using Macro PROCESS by Andrew F. Hayes. The results of this study show that there is a positive effect of e-service quality on the satisfaction of Gojek Yogyakarta customers, there is a positive effect of price perception on the satisfaction of Gojek Yogyakarta customers, there is a positive effect of sales promotion on the satisfaction of Gojek Yogyakarta customers, there is a positive effect of customer satisfaction on the loyalty of Gojek Yogyakarta customers, there is a positive effect of e-service quality on the loyalty of Gojek Yogyakarta customers, there is a positive effect of price perception on the loyalty of Gojek Yogyakarta customers, there is a positive effect of sales promotion on the loyalty of Gojek Yogyakarta customers, and there is the effect of e-service quality, price perception, and sales promotion on customer loyalty through Gojek Yogyakarta customer satisfaction, as evidenced by the e-service quality variable mediation coefficient of 0,0442; the mediation coefficient of price perception variable is 0,0404; and the mediation coefficient of sales promotion variable is 0,0676 .
\end{abstract}

Keywords : E-Service Quality; Price Perception; Sales Promotion; Customer Loyalty; Customer Satisfaction.

\section{PENDAHULUAN}

Perkembangan teknologi yang makin pesat mengakibatkan pengguna internet terus meningkat, tidak terkecuali di Indonesia. Berdasarkan hasil survei Asosiasi Penyelenggara Jasa Internet Indonesia (APJII) tahun 2017 penetrasi pengguna internet sebesar $54,68 \%$ atau 143,26 juta jiwa, meningkat dari tahun 2016 sebesar 132,7 juta jiwa dari total populasi penduduk Indonesia. APJII targetkan sampai akhir 2018 tingkat penetrasi pengguna internet bisa mencapai 60\%. Perkembangan teknologi internet di Indonesia menimbulkan banyak peluang, dan salah satunya ditandai dengan kemunculan sejumlah start up digital pada berbagai bidang. Salah satu start up yang kini telah menjadi perusahaan besar dan menjadi pionir di Indonesia dalam bidang transportasi adalah Gojek. 
PT Gojek Indonesia didirikan pada tahun 2011 oleh Nadiem Makarim dan Michael Angelo Moran. Start up ini bergerak di bidang jasa layanan transportasi dengan menjadi perantara yang menghubungkan pengendara ojek dengan pelanggan. Pada Januari 2015, perusahaan meluncurkan aplikasi mobile Gojek dengan location based search untuk smartphone berbasis android dan iOS. Dengan aplikasi ini, pengendara ojek dapat melihat pesanan yang masuk dan lokasi pemesannya untuk ditanggapi, dan pelanggan dapat memantau posisi pengendara ojek yang menanggapi pesanan tersebut.

Kemunculan Gojek di Indonesia diikuti oleh sejumlah start up transportasi lain dan yang mampu bersaing ketat serta menjadi rival utama Gojek adalah Grab dan Uber. Ketiganya menjadi tiga raksasa perusahaan transportasi daring Indonesia yang terus bersaing satu sama lain untuk memenangkan marketshare. Persaingan diantara ketiganya terus berlanjut sampai Uber terhempas mundur dari Asia Tenggara karena telah diakuisisi oleh Grab pada 26 Maret 2018. Hal ini tentu saja berdampak buruk terhadap Gojek karena Gojek harus berusaha untuk bersaing dengan Grab yang marketshare-nya berkembang secara cepat setelah akuisisi tersebut. Agar terus dapat mempertahankan dan meningkatkan marketshare yang dimiliki, salah satu hal yang dapat dilakukan dengan menjaga dan meningkatkan loyalitas pelanggan.

Lovelock (2010) menyebutkan bahwa loyalitas pelanggan adalah keputusan pelanggan untuk secara sukarela terus berlangganan dengan perusahaan tertentu dalam jangka waktu yang lama. Loyalitas pelanggan memiliki arti penting bagi perusahaan guna menjaga kelangsungan usahanya. Pelanggan yang setia adalah mereka yang sangat puas dengan produk dan pelayanan tertentu, sehingga memiliki antusias untuk mengenalkannya kepada orang-orang yang mereka kenal. Kemudian, pelanggan yang loyal tersebut akan memperluas kesetiaan mereka pada produk atau jasa buatan produsen yang sama.
Loyalitas pelanggan sangatlah mempengaruhi kemajuan sebuah perusahaan. Oleh karenaitu, perusahaan harus tetap menjaga dan mempertahankan para pelanggannya. Salah satu kunci mempertahankan pelanggan adalah dengan menciptakan kepuasan pelanggan. Kotler (2007) menyebutkan bahwa secara umum kepuasan (satisfaction) adalah perasaan senang atau kecewa seseorang yang timbul karena membandingkan kinerja yang dipersepsikan produk (hasil) terhadap ekspektasi mereka. Pelanggan yang puas terhadap barang dan jasa, kemungkinan besar akan membeli ulang dari penyedia barang dan jasa tersebut. Dengan demikian, perusahaan yang mampu memuaskan pelanggan akan dapat meningkatkan keuntungan dan pangsa pasarnya karena adanya pembelian ulang dari pelanggan.

Agar dapat mendorong kepuasan dan loyalitas perusahaan harus memiliki pelayanan yang baik dan unggul dibanding yang lain. Gojek sebagai perusahaan yang bergerak di bidang jasa berbasis internet dapat diukur kualitas pelayanan elektroniknya dengan dimensi pengukuran e-service quality. E-service quality didefinisikan sebagai sejauh mana situs web memfasilitasi pembelanja, pembelian dan pengiriman secara efisien dan efektif (Zeithaml, 2002).

Cara lain yang dilakukan perusahaan dalam mencapai loyalitas adalah dengan memberikan harga yang tepat. Harga merupakan salah satu faktor penentu pembelian dalam menentukan suatu keputusan pembelian terhadap suatu produk maupun jasa yang akan mempengaruhi loyalitas pelanggan. Kotler (2007) mendefinisikan harga sebagai jumlah uang yang dibutuhkan untuk memperoleh beberapa kombinasi sebuah produk dan pelayanan yang menyertainya.

Menurut Schiffman (2000) persepsi adalah proses dimana individu memilih, mengatur dan menafsirkan stimuli ke dalam gambar yang berarti dan masuk akal mengenai dunia. Persepsi mempunyai pengaruh yang kuat bagi konsumen. Salah satu faktor yang berpengaruh terhadap konsumen yaitu 
persepsi terhadap harga. Persepsi harga merupakan kecenderungan konsumen untuk menggunakan harga dalam memberi penilaian tentang kesesuaian manfaat produk. Penilaian terhadap harga pada suatu manfaat produk untuk dapat dikatakan mahal, murah, atau sedang dari setiap individu bisa berbedabeda, bergantung dari persepsi setiap individu yang dilatar belakangi oleh lingkungan dan kondisi individu itu sendiri. Dengan kata lain, konsumen dalam menilai harga suatu produk tidak tergantung hanya dari nilai nominal harga saja, namun dari persepsi mereka pada harga. Perusahaan harus menetapkan harga secara tepat agar dapat sukses dalam memasarkan barang atau jasa.

Faktor lain yang diduga mempengaruhi loyalitas adalah promosi penjualan. Promosi penjualan adalah bagian dari bauran promosi. Kotler (2007) menyebutkan bahwa promosi penjualan merupakan bahan inti dalam kampanye pemasaran yang terdiri dari shortterm incentive dan dirancang untuk mendorong pembelian produk atau jasa tertentu secara lebih cepat atau lebih besar oleh konsumen atau perdagangan. Menurut Peter (1999) bagi konsumen yang terlanjur membeli suatu merek, promosi konsumen dapat menjadi insentif tambahan bagi mereka untuk tetap loyal. Hal ini dikarenakan sebagian konsumen cenderung membeli suatu produk atau jasa didasarkan pada kupon dan tawaran-tawaran yang menarik secara rutin akan membuat mereka relatif loyal pada dimensi promosi penjualan utama. Dari penjelasan tersebut dapat kita ketahui bahwa promosi penjualan dapat menjadi strategi yang tepat untuk mempengaruhi pelanggan agar loyal kepada perusahaan.

\section{REVIEW LITERATUR DAN HIPOTESIS}

\section{Landasan Teori}

\section{Loyalitas Pelanggan}

Menurut Oliver yang disebutkan dalam buku Manajemen Pemasaran oleh
Kotler (2008) mendefinisikan loyalitas (loyalty) sebagai komitmen yang dipegang secara mendalam untuk membeli atau mendukung kembali produk atau jasa yang disukai di masa depan meski pengaruh situasi dan usaha pemasaran berpotensi menyebabkan pelanggan beralih. Griffin (2005) juga menyebutkan bahwa loyalitas adalah perilaku pembelian yang didefinisikan sebagai pembelian non random yang diungkapkan dari waktu ke waktu oleh beberapa unit pengambilan keputusan. Hal ini berarti konsumen yang loyal akan selalu menggunakan suatu produk secara berulang tanpa terpengaruh keadaan.

\section{Kepuasan Pelanggan}

Kotler (2008) menyebutkan bahwa secaraumumkepuasan(satisfaction) adalah perasaan senang atau kecewa seseorang yang timbul karena membandingkan kinerja yang dipersepsikan produk (hasil) terhadap ekspektasi mereka. Apabila kinerja tidak memenuhi ekspektasi, maka pelanggan akan tidak puas, sebaliknya jika kinerja sesuai dengan ekspektasi maka pelanggan tersebut akan puas. Selanjutnya jika kinerja melebihi ekspektasi maka pelanggan akan sangat puas atau senang. Ekspektasi pelanggan tersebut berasal dari pengalaman pembelian masa lalu, nasihat teman dan rekan, serta informasi dan janji pemasar dan pesaing. Akan tetapi jika perusahaan menetapkan ekspektasi yang terlalu rendah, mereka tidak akan mampu menarik cukup pembeli.

\section{E-Service Quality}

E-service quality telah semakin dikenal sebagai saluran penting, dimana kebutuhan pelanggan dapat secara otomatis diberikan melalui internet pada seluruh siklus hidup konsumsi (Abadi, 2012). E-service quality saat ini telah menjadi topik penelitian yang semakin populer, dengan pertumbuhan e-commerce, dan sejumlah penelitian telah menawarkan 
berbagai definisi konseptual. E-service quality didefinisikan sebagai sejauh mana situs web memfasilitasi pembelanja, pembelian, dan pengiriman secara efisien dan efektif (Zeithaml, 2002).

\section{Persepsi Harga}

Menurut Kotler (2008) persepsi adalah suatu proses dimana kita memilih, mengatur, dan menerjemahkan masukan informasi untuk menciptakan gambaran yang berarti tentang dunia. Dengan demikian penilaian terhadap harga suatu produk dikatakan mahal, murah, atau biasa saja dari setiap individu tidaklah harus sama karena tergantung dari persepsi individu yang dilatarbelakangi oleh lingkungan kehidupan dan kondisi individu.

\section{Promosi Penjualan}

Kotler (2007) menyebutkan bahwa promosi penjualan merupakan bahan inti dalam kampanye pemasaran yang terdiri dari short-term incentive dan dirancang untuk mendorong pembelian produk atau jasa tertentu secara lebih cepat atau lebih besar oleh konsumen atau perdagangan. Dengan kata lain, sales promotion merupakan sarana untuk mendorong konsumen agar melakukan pembelian terhadap sebuah produk atau jasa.

\section{Hipotesis}

1. Pengaruh Positif E-Service Quality terhadap Kepuasan Pelanggan

Menurut Zeithaml (2002) e-service quality didefinisikan sebagai sejauh mana situs web memfasilitasi pembelanja, pembelian, dan pengiriman secara efisien dan efektif. Dengan kata lain, semakin efisien dan efektif suatu web atau aplikasi dalam memfasilitasi pelanggan, maka dapat dikatakan semakin baik kualitas pelayanannya. Kualitas pelayanan dan kepuasan pelanggan adalah faktor keberhasilan dari suatu perusahaan untuk mencapai keunggulan bersaing
(Sawitri et al., 2013). Kualitas layanan yang terbaik dapat menciptakan kepuasan pelanggan. Rodgers et al., (2005) melalui penelitiannya mengungkapkan bahwa kualitas sistem dan kualitas layanan adalah faktor penentu yang paling penting untuk kepuasan pelanggan dan loyalitas pelanggan. Berdasarkan uraian di atas, dapat ditarik hipotesis:

\section{H1 :Terdapat Pengaruh Positif E-Service Quality terhadap Kepuasan Pelanggan.}

\section{Pengaruh Positif Persepsi Harga terhadap Kepuasan Pelanggan}

Persepsi harga sering digunakan pelanggan sebagai indikator nilai ketika dihubungkan dengan manfaat yang dirasakan atas suatu barang atau jasa. Pada persepsi harga tertentu apabila manfaat yang dirasakan meningkat, maka nilainya akan meningkat juga. Apabila nilai yang dirasakan pelanggan semakin tinggi, maka akan menciptakan kepuasan pelanggan yang maksimal (Tjiptono, 1999). Menurut Kertajaya (2002) penilaian persepsi harga dapat dilihat dari kesesuaian antara pengorbanan yang diberikan pelanggan dengan nilai yang ia terima setelah melakukan pembelian. Persepsi yang positif akan membentuk kepuasan pelanggan karena pelanggan merasa mendapatkan manfaat atau nilai sesuai dengan pengorbanan yang dia berikan. Berdasarkan uraian di atas, dapat ditarik hipotesis:

\section{H2 :Terdapat Pengaruh Positif Persepsi Harga terhadap Kepuasan Pelanggan.}

\section{Pengaruh Positif Promosi Penjualan terhadap Kepuasan Pelanggan}

Menurut Kotler (2007) promosi penjualan merupakan bahan inti dalam kampanye pemasaran yang terdiri dari short-term incentive dan dirancang untuk mendorong pembelian produk atau jasa tertentu secara lebih cepat atau lebih 
besar oleh konsumen atau perdagangan. Promosi penjualan memiliki tujuan yang beragam. Penjual menggunakan promosi jenis insentif untuk menarik pencoba baru, menghargai pelanggan setia, dan meningkatkan tingkat pembelian kembali pengguna yang jarang membeli. Promosi penjualan menawarkan insentif untuk membeli sehingga manfaat yang ingin diberikan pemasar dapat diterima oleh pelanggan, oleh karena itu kepuasan pelanggan pun meningkat. Penelitian sebelumnya yang dilakukan oleh Yulianto (2017) yang menunjukkan hasil bahwa promosi penjualan berpengaruh positif terhadap kepuasan konsumen. Berdasarkan uraian di atas, dapat ditarik hipotesis:

\section{H3 :Terdapat Pengaruh Positif Promosi Penjualan terhadap Kepuasan Pelanggan.}

\section{Pengaruh Positif Kepuasan Pelanggan terhadap Loyalitas Pelanggan}

Kepuasan pelanggan menjadi tujuan sekaligus sarana pemasaran bagi perusahaan karena salah satu kunci untuk mempertahankan pelanggan adalah kepuasan pelanggan. Kepuasan pelanggan yang tinggi menimbulkan loyalitas pelanggan yang tinggi. Hal ini dikarenakan biasanya pelanggan yang sangat puas akan melakukan halhal yang menjadi indikator loyalitas pelanggan, seperti tetap setia untuk waktu yang lama, membeli lagi ketika perusahaan mengenalkan produk baru dan memperbarui produk lama, membicarakan hal baik tentang perusahaan kepada orang lain, tidak begitu memperhatikan merek lain serta tidak sensitif terhadap harga, bahkan menawarkan ide jasa atau produk baru kepada perusahaan. Penelitian sebelumnya yang dilakukan oleh Laurent (2016) yang menunjukkan hasil bahwa kepuasan pelanggan memberikan pengaruh yang positif terhadap loyalitas pelanggan. Berdasarkan uraian di atas, dapat ditarik hipotesis:

\section{H4:Terdapat Pengaruh Positif Kepuasan Pelanggan terhadap Loyalitas Pelanggan.}

\section{Pengaruh Positif E-Service Quality terhadap Loyalitas Pelanggan}

Semakin efisien dan efektif suatu web atau aplikasi dalam memfasilitasi pelanggan, maka dapat dikatakan semakin baik kualitas pelayanannya. Ketika e-service quality baik, maka akan membuat pelanggan merasa puas karena kinerja web atau aplikasi sesuai dengan harapan mereka. Kepuasan pelanggan yang berkelanjutan dapat menciptakan loyalitas pelanggan yang akan sangat penting bagi kelangsungan hidup perusahaan.

Hal ini sejalan dengan penelitian dari Sundaram (2017) yang menunjukkan bahwa faktor kualitas layanan seperti responsiveness dan trust berpengaruh secara positif terhadap loyalitas secara langsung. Oleh karena itu, kualitas pelayanan online yang diberikan oleh perusahaan melalui website sangat penting untuk diperhatikan dan dijaga kualitasnya karena merupakan komponen utama bagi penyedia jasa online yang dapat mempengaruhi kepuasan dan loyalitas pelanggan. Berdasarkan uraian di atas, dapat ditarik hipotesis:
H5:Terdapat Pengaruh Positif E-Service Quality terhadap Loyalitas Pelanggan.

\section{Pengaruh Positif Persepsi Harga terhadap Loyalitas Pelanggan}

Persepsi harga merupakan faktor penting yang harus diperhatikan oleh perusahaan. Perusahaan harus selalu memonitor harga yang ditetapkan oleh para pesaing, agar harga yang ditentukan oleh perusahaan tersebut tidak terlalu tinggi atau sebaliknya. Menurut Nagle (1995) pada kenyatannya konsumen dalam menilai harga suatu produk sangat tergantung bukan hanya dari nilai nominal 
secara absolut tetapi melalui persepsi mereka pada harga.

Secara spesifik, setiap konsumen menyadari hubungan yang relatif antara harga dan tingkat harapan mereka tentang produk yang akan dibeli. Selanjutnya, jumlah dari suatu harga yang ditawarkan dapat dibandingkan dengan pengalaman dan harapan konsumen sehingga harga yang ditawarkan dapat diterima atau dianggap sesuai dengan kualitas produk yang ditawarkan. Ketika pelanggan merasa harga yang diberikan oleh pemasar sesuai dengan nilai yang mereka terima, maka pelanggan akan merasa puas dan akhirnya akan menciptakan loyalitas pelanggan. Penelitian sebelumnya yang dilakukan oleh Marta (2015) yang menunjukkan hasil bahwa persepsi harga berpengaruh positif terhadap loyalitas pelanggan. Berdasarkan uraian di atas, dapat ditarik hipotesis:

\section{H6 :Terdapat Pengaruh Positif Persepsi Harga terhadap Loyalitas Pelanggan.}

\section{Pengaruh Positif Promosi Penjualan terhadap Loyalitas Pelanggan}

Promosi penjualan memiliki tujuan yang beragam. Menurut Peter (1999) bagi konsumen yang terlanjur membeli suatu merek, promosi konsumen dapat menjadi insentif tambahan bagi mereka untuk tetap loyal. Hal ini dikarenakan sebagian konsumen cenderung membeli suatu produk atau jasa didasarkan pada kupon dan tawaran-tawaran yang menarik secara rutin akan membuat mereka relatif loyal pada dimensi promosi penjualan utama. Dari penjelasan tersebut dapat kita ketahui bahwa promosi penjualan dapat menjadi strategi yang tepat untuk mempengaruhi pelanggan agar loyal kepada perusahaan. Berdasarkan uraian di atas, dapat ditarik hipotesis:

H7 :Terdapat Pengaruh Positif Promosi Penjualan terhadap Loyalitas Pelanggan.

8. Peran Mediasi Kepuasan Pelanggan pada Pengaruh E-Service Quality, Persepsi Harga, dan Promosi Penjualan terhadap Loyalitas Pelanggan

E-service quality, persepsi harga, dan promosi penjualan merupakan suatu kondisi dinamis yang mampu memenuhi dan atau melebihi harapan pelanggan. E-service quality yang baik, persepsi harga yang tepat, dan promosi penjualan yang bagus dapat menjadi keunggulan bersaing bagi perusahaan jasa. Kosumen yang merasa puas secara tidak langsung akan menciptakan loyalitas. Dengan demikian dapat disimpulkan bahwa e-service quality, persepsi harga, dan promosi penjualan dapat menciptakan kepuasan pelanggan dan pada akhirnya akan menumbuhkan loyalitas pelanggan. Penelitian sebelumnya yang dilakukan oleh Marta (2015) yang menunjukkan hasil bahwa terdapat pengaruh persepsi harga, kualitas pelayanan, dan suasana salon terhadap loyalitas pelanggan melalui kepuasan pelanggan sebagai variabel mediasi pada Flaurent Salon Yogyakarta. Berdasarkan uraian di atas, dapat ditarik hipotesis:

H8 :Terdapat Pengaruh E-Service Quality, Persepsi Harga, dan Promosi Penjualan terhadap Loyalitas Pelanggan Melalui Kepuasan Pelanggan sebagai Variabel Mediasi. 


\section{Model Penelitian}

$\mathrm{H}_{5}$

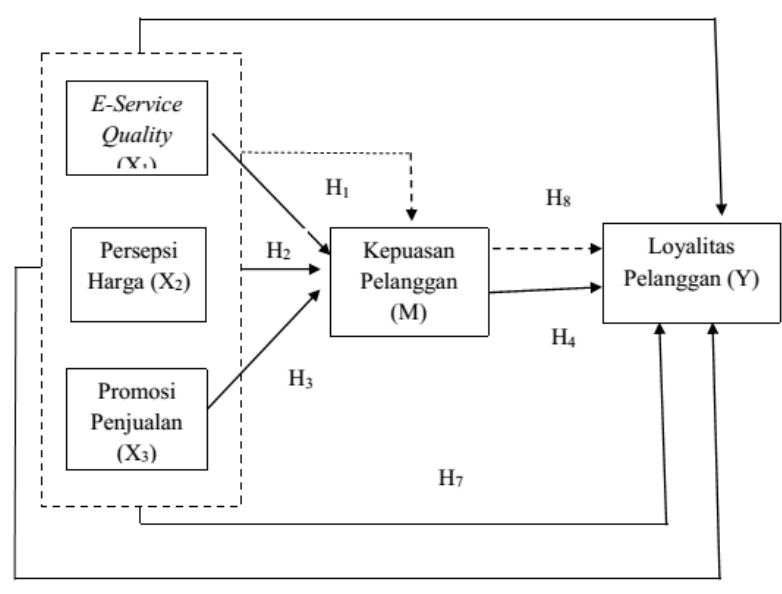

$\mathrm{H}_{6}$

Gambar 2.1

Model Penelitian

\section{METODE PENELITIAN}

\section{Populasi dan Sampel}

Populasi merupakan wilayah generalisasi yang terdiri atas objek atau subjek yang mempunyai kualitas dan karakteristik tertentu yang ditetapkan oleh peneliti untuk dipelajari guna kemudian ditarik kesimpulannya (Sugiyono, 2010). Populasi dalam penelitian ini adalah semua orang yang pernah menggunakan jasa Gojek di Kota Yogyakarta minimal 2 kali dan berusia di atas 18 tahun.

Jumlah pelanggan Gojek tidak dapat diperkirakan sehingga peneliti memutuskan untuk menentukan jumlah sampel dengan menggunakan teknik sampel purposive sampling. Purposive sampling termasuk dalam metode non probability sampling (Sugiyono, 2010). Menurut Sugiyono (2010) purposive sampling adalah teknik penentuan sampel dengan pertimbangan tertentu. Teknik sampel ini cocok digunakan pada populasi yang sangat besar dan ketersediaan populasi sangat banyak. Maka dari itulah digunakan teknik sampel ini karena sifatnya mewakili populasi dan hasil penelitian dapat digeneralisasi terhadap seluruh populasi.
Ukuran responden yang ideal dan representatif menurut Hair et al., (2010) adalah tergantung pada jumlah semua item pertanyaan dikalikan dengan 5-10. Pada penelitian ini, terdapat 47 item pertanyaan. Batas minimal responden untuk penelitian ini adalah $47 \mathrm{x}$ $5=235$. Dengan demikian responden yang akan diambil adalah sebanyak 235 responden. Jumlah tersebut dianggap sudah cukup mewakili populasi yang akan diteliti karena sudah memenuhi batas minimal sampel.

\section{Variabel Penelitian}

\section{Variabel Dependen}

Dalam penelitian ini yang menjadi variabel dependen adalah loyalitas pelanggan (Y). Dalam penelitian ini loyalitas pelanggan yang dimaksud adalah kemauan pelanggan untuk melakukan pembelian ulang atau rutin menggunakan aplikasi Gojek.

\section{Variabel Independen}

\section{a. E-Service Quality}

Menurut Abadi (2012) e-service quality adalah pertemuan antara ekspektasi konsumen tanpa interaksi langsung dalam layanan yang diberikan. E-service quality telah semakin dikenal sebagai saluran penting, dimana kebutuhan pelanggan dapat secara otomatis diberikan melalui internet pada seluruh siklus hidup konsumsi.

\section{b. Persepsi Harga}

Harga merupakan salah satu faktor yang sangat dipertimbangkan pelanggan sebelum melakukan keputusan pembelian produk atau jasa. Terdapat faktor-faktor yang mempengaruhi persepsi harga, diantaranya kemauan, kebutuhan, keinginan, selera, sikap, dan sifat pelanggan, serta tingkat pendapatan pelanggan. Bila semua faktor yang termasuk dalam persepsi harga tersebut baik, maka keputusan 
pembelianpun akan semakin baik atau tinggi.

\section{c. Promosi Penjualan}

Promosi penjualan merupakan bahan inti dalam kampanye pemasaran, terdiri dari koleksi alat insentif, sebagian besar jangka pendek, yang dirancang guna mendorong pembelian yang lebih cepat atau lebih besar atas suatu produk atau jasa tertentu oleh konsumen atau perdagangan.

\section{Variabel Mediasi}

Menurut Truckman dalam Sugiyono (2010) variabel mediasi adalah variabel yang secara teoritis mempengaruhi hubungan antara variabel independen dengan variabel dependen, sehingga menjadi hubungan yang tidak langsung dan tidak dapat diamati dan diukur. Variabel ini merupakan variabel penyela yang terletak di antara variabel independen dan variabel dependen, sehingga variabel independen tidak langsung mempengaruhi berubahnya atau timbulnya variabel dependen.

Variabel mediasi dalam penelitian ini adalah kepuasan pelanggan. Kepuasan pelanggan di dalam penelitian ini diartikan sebagai respon pelanggan yang dirasakan antara harapan sebelumnya dan kinerja aktual produk setelah melakukan pembelian atau penggunaan jasa Gojek.

\section{HASIL PENELITIAN DAN PEMBAHASAN}

\section{Uji Instrumen}

\section{Uji Validitas dengan Confirmatory Factor Analysis (CFA)}

Uji validitas adalah suatu ukuran yang menunjukkan bahwa variabel yang diukur memang benar-benar layak. Uji validitas kuesioner bertujuan untuk mengetahui kehandalan kuesioner. Suatu kuesioner dapat dikatakan valid apabila pertanyaan pada kuesioner mampu untuk mengungkapkan sesuatu yang akan diukur oleh kuesioner tersebut (Ghozali, 2011). Alat uji validitas yang digunakan dalam penelitian ini adalah Confirmatory Factor Analysis (CFA) dengan menggunakan software SPSS.

Hasil Kaiser-Meyer-Olkin Measure of Sampling Adequacy (KMO MSA) dan uji validitas dengan Confirmatory Factor Analysis (CFA) ditunjukkan dalam tabel 4.1 berikut ini:

\section{Tabel 4.1}

\section{KMO and Bartlett's Test Tahap I}

\begin{tabular}{|c|c|c|}
\hline \multicolumn{2}{|c|}{$\begin{array}{l}\text { Kaiser-Meyer-Olkin Measure of Sampling } \\
\text { Adequacy. }\end{array}$} &, 580 \\
\hline Ruequaty. & Approx. Chi-Square & 2291,625 \\
\hline Bartlett's Test of & & 1081 \\
\hline & Sig. & ,000 \\
\hline
\end{tabular}

Berdasarkan hasil penelitian diketahui bahwa nilai Kaiser-Meyer-Olkin Measure of Sampling Adequacy (KMO MSA) lebih besar dari 0,5 yaitu sebesar 0,580 . Hal ini menunjukkan bahwa data yang ada layak untuk dilakukan faktor analisis. Sedangkan pada hasil uji Bartlett's Test of Sphericity diperoleh taraf signifikansi 0,000 , yang artinya terdapat korelasi antar variabel (signifikansi $<0,05$ ). Dengan demikian dapat disimpulkan bahwa semua variabel yang ada dapat dianalisis lebih lanjut karena telah memenuhi kriteria.

Selanjutnya pada tabel berikut ini menunjukkan bahwa semua item pernyataan pada masing-masing variabel mengelompok menjadi satu, dengan nilai loading factor di atas 0,5 . Hal ini menunjukkan bahwa indikator tersebut merupakan satu kesatuan alat ukur yang mengukur satu konstruk yang sama dan dapat memprediksi apa yang seharusnya diprediksi. 
Tabel 4.2

Rotated Component Matrix

\begin{tabular}{|c|c|c|c|c|c|}
\hline & & & ompone & & \\
\hline & 1 & 2 & 3 & 4 & 5 \\
\hline E-Service 1 & & & & 0,571 & \\
\hline E-Service 2 & & & & 0,585 & \\
\hline E-Service 3 & & & & 0,580 & \\
\hline E-Service 4 & & & & 0,581 & \\
\hline E-Service 5 & & & & & \\
\hline E-Service 6 & & & & 0,569 & \\
\hline E-Service 7 & & & & 0,743 & \\
\hline E-Service 8 & & & & 0,760 & \\
\hline E-Service 9 & & & & 0,649 & \\
\hline E-Service 10 & & & & 0,653 & \\
\hline E-Service 11 & & & & 0,760 & \\
\hline Harga 1 & 0,641 & & & & \\
\hline Harga 2 & 0,657 & & & & \\
\hline Harga 3 & 0,589 & & & & \\
\hline Harga 4 & & & & & \\
\hline Harga 5 & 0,594 & & & & \\
\hline Harga 6 & 0,661 & & & & \\
\hline Harga 7 & 0,561 & & & & \\
\hline Harga 8 & 0,628 & & & & \\
\hline Harga 9 & 0,680 & & & & \\
\hline Harga 10 & 0,505 & & & & \\
\hline Harga 11 & 0,514 & & & & \\
\hline Harga 12 & 0,642 & & & & \\
\hline Promosi I & & 0,748 & & & \\
\hline Promosi 2 & & 0,690 & & & \\
\hline Promosi 3 & & 0,714 & & & \\
\hline Promosi 4 & & 0,720 & & & \\
\hline Promosi 5 & & 0,545 & & & \\
\hline Promosi 6 & & 0,690 & & & \\
\hline Promosi 7 & & 0,696 & & & \\
\hline Loyalitas 1 & & & 0,550 & & \\
\hline Loyalitas 2 & & & 0,619 & & \\
\hline Loyalitas 3 & & & 0,518 & & \\
\hline Loyalitas 4 & & & 0,659 & & \\
\hline Loyalitas 5 & & & 0,546 & & \\
\hline Loyalitas 6 & & & 0,674 & & \\
\hline Loyalitas 7 & & & 0,745 & & \\
\hline Loyalitas 8 & & & 0,665 & & \\
\hline Kepuasan 1 & & & & & 0,598 \\
\hline Kepuasan 2 & & & & & \\
\hline Kepuasan 3 & & & & & 0,696 \\
\hline Kepuasan 4 & & & & & 0,607 \\
\hline Kepuasan 5 & & & & & 0,712 \\
\hline Kepuasan 6 & & & & & 0,684 \\
\hline Kepuasan 7 & & & & & 0,642 \\
\hline Kepuasan 8 & & & & & 0,590 \\
\hline Kepuasan 9 & & & & & 0,527 \\
\hline
\end{tabular}

Berdasarkan tabel 4.2 di atas diketahui bahwa meskipun semua item telah mengelompok sesuai dengan indikatornya, akan tetapi berdasarkan hasil di atas diketahui bahwa tidak semua item pernyataan dinyatakan valid. Item e-service quality 5 , item persepsi harga 4, dan item kepuasan 2 dinyatakan gugur karena memiliki nilai loading factor di bawah 0,5. Dikarenakan uji CFA pada tahap 1 terdapat sejumlah butir pertanyaan yang gugur, maka perlu dilakukan uji CFA tahap 2. Hasil Kaiser-MeyerOlkin Measure of Sampling Adequacy (KMO MSA) dan uji validitas dengan Confirmatory Factor Analysis (CFA) tahap 2 ditunjukkan dalam tabel berikut ini:

Tabel 4.3

KMO and Bartlett's Test Tahap II

\begin{tabular}{|ll|r|}
\hline Kaiser-Meyer-0lkin & Measure of Sampling Adequacy. &, 657 \\
Bartlett's Test of & Approx. Chi-Square & 2103,655 \\
Sphericity & Df & 946 \\
& Sig. &, 000 \\
\hline
\end{tabular}

Berdasarkan hasil penelitian diketahui bahwa nilai Kaiser-Meyer-Olkin Measure of Sampling Adequacy (KMO MSA) lebih besar dari 0,5, yaitu sebesar 0,657. Hal ini menunjukkan bahwa data yang ada layak untuk dilakukan faktor analisis. Sedangkan pada hasil uji Bartlett's Test of Sphericity diperoleh taraf signifikansi 0,000 , yang artinya terdapat korelasi antar variabel (signifikansi $<0,05$ ). Dengan demikian dapat disimpulkan bahwa semua variabel yang ada dapat dianalisis lebih lanjut karena telah memenuhi kriteria.

Selanjutnya pada tabel di bawah ini menunjukkan bahwa semua item pernyataan pada masing-masing variabel mengelompok menjadi satu, dengan nilai loading factor di atas 0,5 . Hal ini menunjukkan bahwa indikator tersebut merupakan satu kesatuan alat ukur yang mengukur satu konstruk yang sama dan dapat memprediksi apa yang seharusnya diprediksi. 
Peran Mediasi Kepuasan Pelanggan pada Pengaruh E-Service Quality, Persepsi Harga, dan Promosi Penjualan terhadap Loyalitas Pelanggan

Tabel 4.4

Rotated Component Matrix

\begin{tabular}{|c|c|c|c|c|c|}
\hline & & & Compone & & \\
\hline & 1 & 2 & 3 & 4 & 5 \\
\hline E-Service 1 & & & & 0,594 & \\
\hline E-Service 2 & & & & 0,625 & \\
\hline \begin{tabular}{|l|} 
E-Service 3 \\
\end{tabular} & & & & 0,530 & \\
\hline E-Service 4 & & & & 0,605 & \\
\hline E-Service 6 & & & & 0,598 & \\
\hline E-Service 7 & & & & 0,746 & \\
\hline E-Service 8 & & & & 0,741 & \\
\hline E-Service 9 & & & & 0,663 & \\
\hline E-Service 10 & & & & 0,652 & \\
\hline E-Service 11 & & & & 0,760 & \\
\hline \begin{tabular}{|l|} 
Harga 1 \\
\end{tabular} & 0,637 & & & & \\
\hline $\begin{array}{l}\text { Harga } 2 \\
\end{array}$ & 0,660 & & & & \\
\hline Harga 3 & 0,541 & & & & \\
\hline Harga 5 & 0,597 & & & & \\
\hline Harga 6 & 0,678 & & & & \\
\hline Harga 7 & 0,522 & & & & \\
\hline Harga 8 & 0,636 & & & & \\
\hline Harga 9 & 0,679 & & & & \\
\hline \begin{tabular}{|l} 
Harga 10 \\
\end{tabular} & 0,690 & & & & \\
\hline \begin{tabular}{|l|} 
Harga 11 \\
\end{tabular} & 0,642 & & & & \\
\hline \begin{tabular}{|l|} 
Harga 12 \\
\end{tabular} & 0,599 & & & & \\
\hline \begin{tabular}{|l|} 
Promosi 1 \\
\end{tabular} & & 0,767 & & & \\
\hline \begin{tabular}{|l|} 
Promosi 2 \\
\end{tabular} & & 0,694 & & & \\
\hline \begin{tabular}{|l|} 
Promosi 3 \\
\end{tabular} & & 0,725 & & & \\
\hline \begin{tabular}{|l|} 
Promosi 4 \\
\end{tabular} & & 0,741 & & & \\
\hline \begin{tabular}{|l|} 
Promosi 5 \\
\end{tabular} & & 0,546 & & & \\
\hline \begin{tabular}{|l|} 
Promosi 6 \\
\end{tabular} & & 0,712 & & & \\
\hline \begin{tabular}{|l|} 
Promosi 7 \\
\end{tabular} & & 0,724 & & & \\
\hline \begin{tabular}{|l|} 
Loyalitas 1 \\
\end{tabular} & & & 0,545 & & \\
\hline \begin{tabular}{|l} 
Loyalitas 2 \\
\end{tabular} & & & 0,666 & & \\
\hline Loyalitas 3 & & & 0,502 & & \\
\hline \begin{tabular}{|l|} 
Loyalitas 4 \\
\end{tabular} & & & 0,679 & & \\
\hline \begin{tabular}{|l|} 
Loyalitas 5 \\
\end{tabular} & & & 0,509 & & \\
\hline \begin{tabular}{|l} 
Loyalitas 6 \\
\end{tabular} & & & 0,648 & & \\
\hline \begin{tabular}{|l|} 
Loyalitas 7 \\
\end{tabular} & & & 0,727 & & \\
\hline \begin{tabular}{|l} 
Loyalitas 8 \\
\end{tabular} & & & 0,599 & & \\
\hline Kepuasan 1 & & & & & 0,617 \\
\hline \begin{tabular}{|l|} 
Kepuasan 3 \\
\end{tabular} & & & & & 0,695 \\
\hline Kepuasan 4 & & & & & 0,657 \\
\hline Kepuasan 5 & & & & & 0,736 \\
\hline Kepuasan 6 & & & & & 0,681 \\
\hline Kepuasan 7 & & & & & 0,595 \\
\hline Kepuasan 8 & & & & & 0,649 \\
\hline Kepuasan 9 & & & & & 0,517 \\
\hline
\end{tabular}

Berdasarkan hasil uji CFA tahap 2 diketahui bahwa semua item telah mengelompok sesuai dengan indikatornya dan berdasarkan hasil di atas diketahui semua item pernyataan dinyatakan valid dengan nilai loading factor di atas 0,5 .

\section{Uji Reliabilitas}

Uji reliabilitas kuesioner dilakukan dengan tujuan untuk mengetahui konsistensi derajat ketergantungan dan stabilitas dari alat ukur. Suatu kuesioner dikatakan reliabel atau handal jika jawaban seseorang terhadap pernyataan adalah konsisten atau stabil dari waktu ke waktu (Ghozali, 2011). Instrumen yang reliabel adalah instrumen yang ketika dilakukan pengukuran secara berulang-ulang pada kelompok yang sama akan menghasilkan hasil yang relatif sama, selama aspek yang diukur tidak berubah.

Pengujian reliabilitas terhadap seluruh butir pertanyaan yang digunakan dalam penelitian ini akan menggunakan uji statistik cronbach's alpha dimana suatu variabel dianggap reliabel apabila nilai cronbach's alpha-nya $>0,7$ meskipun 0,6 masih dapat diterima (Ghozali, 2011). Hasil uji reliabilitas disajikan pada tabel 4.5 di bawah ini:

Tabel 4.5

Hasil Uji Reliabilitas

\begin{tabular}{|l|l|l|l|}
\hline Variabel & Batas Normal & $\begin{array}{l}\text { Nilai Cronbach } \\
\text { Alpha }\end{array}$ & Keterangan \\
\hline E Service Quality & $>0,60$ & 0,835 & Reliabel \\
\hline Persepsi Harga & $>0,60$ & 0,909 & Reliabel \\
\hline Promosi Penjualan & $>0,60$ & 0,780 & Reliabel \\
\hline $\begin{array}{l}\text { Kepuasan } \\
\text { Pelanggan }\end{array}$ & $>0,60$ & 0,835 & Reliabel \\
\hline $\begin{array}{l}\text { Loyalitas } \\
\text { Pelanggan }\end{array}$ & $>0,60$ & 0,883 & Reliabel \\
\hline
\end{tabular}

Hasil uji reliabilitas menunjukkan bahwa semua item pertanyaan dari variabel yang diteliti adalah reliabel, karena mempunyai nilai cronbach's alpha $>0,7$.

\section{Analisis Deskriptif}

Analisis ini dimaksudkan untuk mendeskripsikan atau memberikan gambaran terhadap objek yang diteliti melalui data sampel atau populasi sebagaimana adanya, tanpa melakukan analisis dan membuat kesimpulan yang berlaku umum. Dalam hal ini, akan dikemukakan penyajian dapat berupa tabel biasa atau distribusi frekuensi, grafik, diagram, piktogram, penjelasan kelompok melalui modus, median, mean, dan variasi kelompok melalui rentang dan simpangan baku (Sugiyono, 2010). Hal yang disajikan dalam analisis deskriptif pada penelitian ini meliputi karakteristik responden. 
Tabel 4.6

Berdasarkan Penghasilan

\begin{tabular}{|l|c|c|}
\hline Penghasilan & Frekuensi & Persentase(\%) \\
\hline$<$ Rp 1.000 .000 & 131 & 55,7 \\
\hline $\begin{array}{l}\text { Rp } 1.000 .000 \mathrm{~s} / \mathrm{d} \\
\text { Rp } 1.500 .000\end{array}$ & 57 & 24,3 \\
\hline $\begin{array}{l}\text { Rp } 1.600 .000 \mathrm{~s} / \mathrm{d} \\
\text { Rp } 2.000 .000\end{array}$ & 22 & 9,3 \\
\hline$>$ Rp 2.000.000 & 25 & 10,7 \\
\hline Jumlah & 235 & 100,0 \\
\hline
\end{tabular}

Tabel 4.6 di atas menunjukkan bahwa responden yang berpenghasilan kurang dari Rp 1.000 .000 sebanyak 131 orang, Rp $1.000 .000 \mathrm{~s} / \mathrm{d}$ Rp 1.500.000 sebanyak 57 orang, Rp 1.600.000 s/d 2.000.000 sebanyak 22 orang, dan lebih dari Rp 2.000.000 sebanyak 25 orang.

Tabel 4.7

Berdasarkan Usia

\begin{tabular}{|c|c|c|}
\hline Usia & Frekuensi & Persentase (\%) \\
\hline 18-22 tahun & 198 & 84,3 \\
\hline $23-27$ tahun & 29 & 12,3 \\
\hline$>27$ tahun & 8 & 3,4 \\
\hline Jumlah & 235 & 100,0 \\
\hline
\end{tabular}

Tabel 4.7 di atas menunjukkan bahwa responden yang berusia antara 18-22 tahun sebanyak 198 orang, berusia antara 23-27 tahun sebanyak 29 orang, dan berusia $>27$ tahun sebanyak 8 orang.

\section{Tabel 4.8}

Berdasarkan Pendidikan Terakhir

\begin{tabular}{|c|r|r|}
\hline Pendidikan Terakhir & Frekuensi & Persentase (\%) \\
\hline SD & 0 & 0 \\
\hline SMP & 0 & 0 \\
\hline SMA & 180 & 76,6 \\
\hline Perguruan Tinggi & 55 & 23,4 \\
\hline Jumlah & 235 & 100,0 \\
\hline
\end{tabular}

Tabel 4.8 di atas menunjukkan bahwa tidak ada responden yang pendidikan terakhirnya SD dan SMP. Responden yang pendidikan terakhirnya SMA sebanyak 180 orang dan responden yang pendidikan terakhirnya mencapai perguruan tinggi sebanyak 55 orang.
Tabel 4.9

Berdasarkan Pekerjaan

\begin{tabular}{|l|c|c|}
\hline Pekerjaan & Frekuensi & Persentase $(\%)$ \\
\hline PNS & 1 & 0,4 \\
\hline Karyawan Swasta & 13 & 5,6 \\
\hline Wiraswasta & 7 & 3,0 \\
\hline Pelajar/Mahasiswa & 214 & 91,0 \\
\hline Jumlah & 235 & 100,0 \\
\hline
\end{tabular}

Tabel 4.9 di atas menunjukkan bahwa responden yang pekerjaannya sebagai PNS sebanyak 1 orang, karyawan swasta sebanyak 13 orang, wiraswasta sebanyak 7 orang dan responden yang masih berstatus sebagai pelajar atau mahasiswa sebanyak 214 orang.

\section{Uji Prasyarat Analisis}

\section{Uji Normalitas}

Pengujian ini dilakukan untuk memenuhi prasyarat uji $\mathrm{T}$ yang mengasumsikan bahwa nilai residual mengikuti distribusi normal. Ada dua cara untuk mendeteksi residual berdistribusi normal atau tidak, yaitu dengan analisis grafik dan uji statistik (Ghozali, 2011). Untuk menguji normalitas residual digunakan uji statistik non parametik Kolmogorov Smirnov (K-S).

Pengujian normalitas dilakukan dengan melihat nilai signifikansi 2-tailed. Jika data memiliki tingkat signifikansi lebih dari atau sama dengan 0,05, maka dapat disimpulkan bahwa $\mathrm{H} 0$ diterima sehingga data dikatakan berdistribusi normal (Ghozali, 2011).

Tabel 4.10

Hsil Uji Normalitas

\begin{tabular}{|l|c|c|}
\hline \multicolumn{1}{|c|}{ Variabel } & Signifikansi & Keterangan \\
\hline E Service Quality & 0,366 & Normal \\
\hline Persepsi Harga & 0,542 & Normal \\
\hline Promosi Penjualan & 0,054 & Normal \\
\hline Kepuasan Pelanggan & 0,053 & Normal \\
\hline Loyalitas Pelanggan & 0,051 & Normal \\
\hline
\end{tabular}

Hasil uji normalitas di atas dapat diketahui bahwa semua variabel penelitian mempunyai nilai signifikansi lebih besar dari 0,05 , sehingga dapat disimpulkan bahwa data penelitian berdistribusi normal. 
Peran Mediasi Kepuasan Pelanggan pada Pengaruh E-Service Quality, Persepsi Harga, dan Promosi Penjualan terhadap Loyalitas Pelanggan

\section{Uji Heteroskedastisitas}

Uji heteroskedastisitas dilakukan untuk menguji apakah dalam sebuah model regresi terjadi ketidaksamaan varians dari residual satu pengamatan ke pengamatan yang lain. Jika varians dari residual dari satu pengamatan ke pengamatan lain tetap, maka disebut dengan homokedastisitas dan bila berbeda disebut dengan heteroskedastisitas. Regresi yang baik adalah yang terjadi homokedastisitas atau tidak terjadi heterokedastisitas (Ghozali, 2011). Salah satu cara untuk melihat ada tidaknya heteroskedastisitas adalah menggunakan uji glejser. Regresi tidak mengandung heteroskedastisitas jika probabilitas signifikansinya $>0,05$ (Ghozali, 2011).

\section{Tabel 4.11}

Hasil Uji Heteroskedastisitas

\begin{tabular}{|l|c|c|}
\hline \multicolumn{1}{|c|}{ Dimensi } & Sig. & \multicolumn{1}{c|}{ Kesimpulan } \\
\hline E Service Quality & 0,206 & Tidak terjadi heteroskedastisitas \\
\hline Persepsi Harga & 0,053 & Tidak terjadi heteroskedastisitas \\
\hline Promosi Penjualan & 0,126 & Tidak terjadi heteroskedastisitas \\
\hline Kepuasan Pelanggan & 0,062 & Tidak terjadi heteroskedastisitas \\
\hline
\end{tabular}

Tabel 4.11 di atas menunjukkan bahwa semua variabel mempunyai nilai signifikansi lebih besar dari 0,05 , sehingga dapat disimpulkan bahwa model regresi pada penelitian ini tidak terjadi heteroskedastisitas.

\section{Uji Multikolinieritas}

Uji multikolinieritas bertujuan untuk menguji apakah model regresi ditemukan adanya korelasi antar variabel bebas. Model regresi yang baik seharusnya tidak terjadi korelasi di antara variabel bebas. Nilai korelasi tersebut dapat dilihat dari collinearity statistics. Apabila nilai VIF (Variance Inflation Factor) memperlihatkan hasil yang $>10$ dan nilai tolerance tidak boleh lebih kecil dari 0,1, maka gejala multikolinieritas tidak ada (Ghozali, 2011).
Tabel 4.12

Hasil Uji Multikolinieritas

\begin{tabular}{|l|c|c|l|}
\hline \multicolumn{1}{|c|}{ Dimensi } & Tolerance & VIF & Kesimpulan \\
\hline E Service Quality & 0,956 & 1,046 & $\begin{array}{l}\text { Tidak terjadi } \\
\text { multikolinieritas }\end{array}$ \\
\hline Persepsi Harga & 0,948 & 1,055 & $\begin{array}{l}\text { Tidak terjadi } \\
\text { multikolinieritas }\end{array}$ \\
\hline Promosi Penjualan & 0,893 & 1,119 & $\begin{array}{l}\text { Tidak terjadi } \\
\text { multikolinieritas }\end{array}$ \\
\hline Kepuasan Pelanggan & 0,916 & 1,092 & $\begin{array}{l}\text { Tidak terjadi } \\
\text { multikolinieritas }\end{array}$ \\
\hline
\end{tabular}

Dari tabel 4.12 di atas terlihat bahwa semua variabel mempunyai nilai toleransi di atas 0,1 dan nilai VIF di bawah 10 , sehingga dapat disimpulkan bahwa model regresi pada penelitian ini tidak terjadi multikolinieritas.

\section{Uji Linieritas}

Uji ini digunakan untuk melihat apakah regresi antara $\mathrm{X}$ dan $\mathrm{Y}$ membentuk garis linier atau tidak. Kalau tidak linier maka analisis regresi tidak dapat dilanjutkan (Sugiyono, 2010). Kriteria pengujian linearitas adalah jika nilai signifikansi $>0,05$, maka hubungan antara variabel independen dengan variabel dependen adalah linier.

Tabel 4.13

Hasil Uji Linieritas

\begin{tabular}{|l|c|c|}
\hline \multicolumn{1}{|c|}{ Variabel } & Signifikansi & Keterangan \\
\hline E Service Quality & 0,224 & Linier \\
\hline Persepsi harga & 0,408 & Linier \\
\hline Promosi Penjualan & 0,268 & Linier \\
\hline Kepuasan Pelanggan & 0,292 & Linier \\
\hline
\end{tabular}

Hasil uji linieritas pada tabel 4.13 di atas dapat diketahui bahwa semua variabel memiliki nilai signifikansi yang $>$ dari 0,05 . Hal ini menunjukkan bahwa semua variabel penelitian adalah linier.

\section{Uji Hipotesis}

\section{Uji Parsial (Uji T)}

Uji $\mathrm{T}$ digunakan untuk menguji pengaruh variabel independen secara parsial terhadap variabel dependen. Pengujian ini dilakukan dengan ketentuan sebagai berikut: 
a. Jika tingkat signifikansi lebih besar 0,05, maka disimpulkan bahwa hipotesis ditolak.

b. Jika tingkat signifikansi lebih kecil 0,05 , maka dapat disimpulkan bahwa hipotesis diterima.

Tabel 4.14

Hasil Uji Hipotesis Pertama

\begin{tabular}{|c|c|c|c|c|}
\hline Konstanta & $\begin{array}{c}\text { Koefisien } \\
\text { Regresi }\end{array}$ & thitung & Sig. & $\begin{array}{c}\text { Adjusted } \\
\mathbf{R}^{\mathbf{2}}\end{array}$ \\
\hline 23,852 & 0,164 & 3,123 & 0,012 & 0,077 \\
\hline
\end{tabular}

Hasil uji $\mathrm{T}$ menunjukkan tingkat signifikansi 0,012 yang mana lebih kecil dari $0,05(0,012<0,05)$, serta koefisien regresi mempunyai nilai sebesar 0,164 . Hipotesis pertama yang menyatakan bahwa terdapat pengaruh positif e-service quality terhadap kepuasan pelanggan Gojek Yogyakarta diterima.

Tabel 4.15

Hasil Uji Hipotesis Kedua

\begin{tabular}{|c|c|c|c|c|}
\hline Konstanta & $\begin{array}{c}\text { Koefisien } \\
\text { Regresi }\end{array}$ & $\begin{array}{c}\mathbf{t} \\
\text { hitung }\end{array}$ & Sig. & $\begin{array}{c}\text { Adjusted } \\
\mathbf{R}^{2}\end{array}$ \\
\hline 23,782 & 0,153 & 2,726 & 0,007 & 0,027 \\
\hline
\end{tabular}

Hasil uji $\mathrm{T}$ menunjukkan tingkat signifikansi 0,007 yang mana lebih kecil dari $0,05(0,007<0,05)$, serta koefisien regresi mempunyai nilai sebesar 0,153 . Hipotesis kedua yang menyatakan bahwa terdapat pengaruh positif persepsi harga terhadap kepuasan pelanggan Gojek Yogyakarta diterima.

Tabel 4.16

Hasil Uji Hipotesis Ketiga

\begin{tabular}{|c|c|c|c|c|}
\hline Konstanta & $\begin{array}{c}\text { Koefisien } \\
\text { Regresi }\end{array}$ & thitung & Sig. & Adjusted $\mathbf{R}^{2}$ \\
\hline 22,116 & 0,317 & 4,044 & 0,000 & 0,062 \\
\hline
\end{tabular}

Hasil uji $\mathrm{T}$ menunjukkan tingkat signifikansi 0,000 yang lebih kecil dari $0,05(0,000<0,05)$, serta koefisien regresi mempunyai nilai sebesar 0,317 . Hipotesis ketiga yang menyatakan bahwa terdapat pengaruh positif promosi penjualan terhadap kepuasan pelanggan Gojek Yogyakarta diterima.
Tabel 4.17

Hasil Uji Hipotesis Keempat

\begin{tabular}{|c|c|c|c|c|}
\hline Konstanta & $\begin{array}{c}\text { Koefisien } \\
\text { Regresi }\end{array}$ & $\begin{array}{c}\mathbf{t} \\
\text { hitung }\end{array}$ & Sig. & $\begin{array}{c}\text { Adjust } \\
\text { ed } \mathbf{R}^{\mathbf{2}}\end{array}$ \\
\hline 21,290 & 0,304 & 4,458 & 0,000 & 0,075 \\
\hline
\end{tabular}

Hasil uji $\mathrm{T}$ menunjukkan tingkat signifikansi 0,000 yang mana lebih kecil dari $0,05(0,000<0,05)$, serta koefisien regresi mempunyai nilai sebesar 0,304 . Hipotesis keempat yang menyatakan bahwa terdapat pengaruh positif kepuasan pelanggan terhadap loyalitas pelanggan Gojek Yogyakarta diterima.

Tabel 4.18

Hasil Uji Hipotesis Kelima

\begin{tabular}{c|c|c|c|c|}
\hline Konstanta & $\begin{array}{c}\text { Koefisien } \\
\text { Regresi }\end{array}$ & $\begin{array}{c}\mathbf{t} \\
\text { hitung }\end{array}$ & Sig. & $\begin{array}{c}\text { Adjusted } \\
\mathbf{R}^{2}\end{array}$ \\
\hline 14,636 & 0,446 & 5,726 & 0,000 & 0,120 \\
\hline
\end{tabular}

Hasil uji $\mathrm{T}$ menunjukkan tingkat signifikansi 0,000 yang mana lebih kecil dari $0,05(0,000<0,05)$, serta koefisien regresi mempunyai nilai sebesar 0,446 . Hipotesis kelima yang menyatakan bahwa terdapat pengaruh positif e-service quality terhadap loyalitas pelanggan Gojek Yogyakarta diterima.

Tabel 4.19

Hasil Uji Hipotesis Keenam

\begin{tabular}{|c|c|c|c|c|}
\hline Konstanta & $\begin{array}{c}\text { Koefisien } \\
\text { Regresi }\end{array}$ & $\begin{array}{c}\mathbf{t} \\
\text { hitung }\end{array}$ & $\begin{array}{c}\text { Sig. } \\
\text { Adjusted } \\
\mathbf{R}^{\mathbf{2}}\end{array}$ \\
\hline 20,949 & 0,241 & 4,022 & 0,000 & 0,061 \\
\hline
\end{tabular}

Hasil uji $\mathrm{T}$ menunjukkan tingkat signifikansi 0,000 yang mana lebih kecil dari $0,05(0,000<0,05)$, serta koefisien regresi mempunyai nilai sebesar 0,241. Hipotesis keenam yang menyatakan bahwa terdapat pengaruh positif persepsi harga terhadap loyalitas pelanggan Gojek Yogyakarta diterima.

Tabel 4.20

Hasil Uji Hipotesis Ketujuh

\begin{tabular}{|c|c|c|c|c|}
\hline Konstanta & $\begin{array}{c}\text { Koefisien } \\
\text { Regresi }\end{array}$ & t hitung & Sig. & $\begin{array}{c}\text { Adjusted } \\
\mathbf{R}^{\mathbf{2}}\end{array}$ \\
\hline 18,184 & 0,503 & 6,190 & 0,000 & 0,138 \\
\hline
\end{tabular}

Hasil uji $\mathrm{T}$ menunjukkan tingkat signifikansi 0,000 yang mana lebih kecil dari $0,05(0,000<0,05)$, serta koefisien regresi mempunyai nilai sebesar 0,503. Hipotesis ketujuh yang menyatakan 
Peran Mediasi Kepuasan Pelanggan pada Pengaruh E-Service Quality, Persepsi Harga, dan Promosi Penjualan terhadap Loyalitas Pelanggan

bahwa terdapat pengaruh positif promosi penjualan terhadap loyalitas pelanggan Gojek Yogyakarta diterima.

\section{Metode Bootstrapping dengan Macro PROCESS}

Baron (1986) menyebut suatu variabel disebut mediator jika variabel tersebut ikut mempengaruhi hubungan antara variabel independen dan dependen. Model mediasi memiliki hipotesis bahwa variabel independen mempengaruhi variabel mediator, yang pada gilirannya mempengaruhi variabel dependen. Terdapat sejumlah metode yang bisa digunakan untuk menganalisis variabel mediator. Hayes (2013) merekomendasikan penggunaan metode bootstrapping dengan Macro PROCESS. Berikut adalah metode Bootstrapping dengan Macro PROCESS untuk hipotesis kedelapan:

\section{Tabel 4.21}

\section{Bootstrapping E-Service Quality}

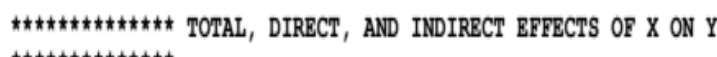

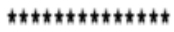

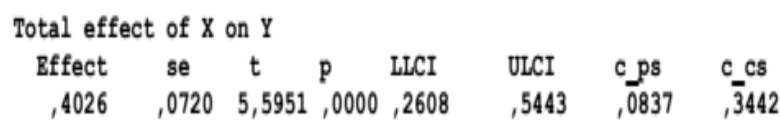

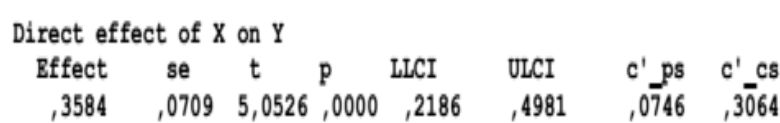

Indirect effect(s) of $\mathrm{X}$ on $\mathrm{Y}$ :

$\begin{array}{rrrrr} & \text { Bffect } & \text { BootSB } & \text { BootLLCI } & \text { BootULCI } \\ \text { Kepuasan } & , 0442 & , 0208 & , 0082 & , 0883\end{array}$

Tabel 4.21 pada bagian indirect effect terlihat pengaruh tidak langsung e-service quality terhadap loyalitas pelanggan melalui kepuasan pelanggan Gojek Yogyakarta. Dalam hal ini besarnya pengaruh tidak langsung adalah 0,0442, sehingga dapat disimpulkan terjadi hubungan mediasi secara positif.
Tabel 4.22

Bootstrapping Persepsi Harga ************* TOMAL, DIRECT, AND INDIRECT BRFBCTS OF X ON Y *************

Total effect of $X$ on $Y$

$\begin{array}{ccccccc}\text { Effect se } & t & p & \text { LLCI } & \text { OLCI } & \text { c.ps } & \text { c cs } \\ , 2407,0599 & 4,0219 & , 0001,1228 & , 3587 & , 0501 & 2548\end{array}$

Direct effect of $X$ on $Y$

Bffect se $t$ p LLCI ULCI c'ps c'cs 2004, 20590 3,3938, 0008, 0840 , 3167

Indirect effect (s) of $\mathrm{X}$ on $\mathrm{Y}$ :

$\begin{array}{rrrrr} & \text { Bffect } & \text { BootSB } & \text { BootLLCI } & \text { BootULCI } \\ \text { Repuasan } & , 0404 & , 0178 & , 0090 & , 0785\end{array}$

Tabel 4.22 pada bagian indirect effect terlihat pengaruh tidak langsung persepsi harga terhadap loyalitas pelanggan melalui kepuasan pelanggan Gojek Yogyakarta. Dalam hal ini besarnya pengaruh tidak langsung adalah 0,0404, sehingga dapat disimpulkan terjadi hubungan mediasi secara positif.

Tabel 4.23

Bootstrapping Promosi Penjualan

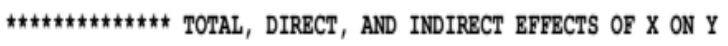

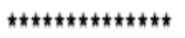

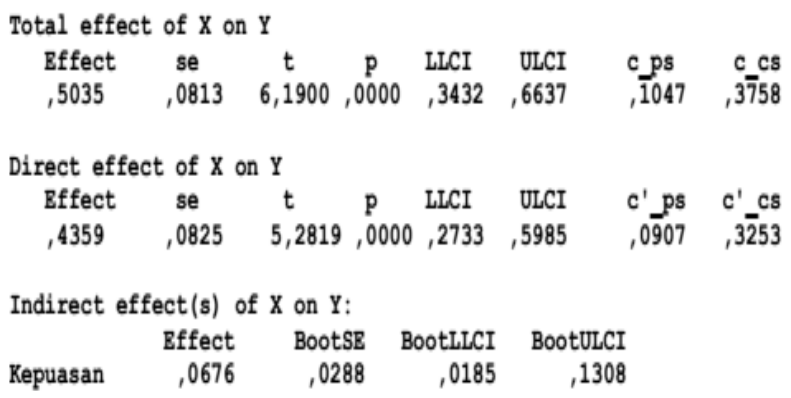

Tabel 4.23 pada bagian indirect effect terlihat pengaruh tidak langsung promosi penjualan terhadap loyalitas pelanggan melalui kepuasan pelanggan Gojek Yogyakarta. Dalam hal ini besarnya pengaruh tidak langsung adalah 0,0676, sehingga dapat disimpulkan terjadi hubungan mediasi secara positif.

\section{Pembahasan}

1. Pengaruh Positif E-Service Quality terhadap Kepuasan Pelanggan

Hasil uji $\mathrm{T}$ menunjukkan tingkat signifikansi 0,012 yang mana lebih kecil dari $0,05(0,012<0,05)$, serta koefisien 
regresi mempunyai nilai sebesar 0,164. Maka penelitian ini berhasil membuktikan hipotesis pertama yang menyatakan terdapat pengaruh positif e-service quality terhadap kepuasan pelanggan Gojek Yogyakarta.

Kepuasan pelanggan merupakan perasaan senang atau kecewa seseorang yang timbul, karena membandingkan kinerja produk yang dipersepsikan dengan ekspektasi mereka. Dalam hal ini pelanggan akan mempersepsikan dan berekspektasi terkait kinerja aplikasi Gojek, apakah aplikasi Gojek dapat memfasilitasi mereka secara efektif dan efisien. Jika kinerja aplikasi sesuai atau melebihi ekspektasi pelanggan, maka pelanggan akan puas bahkan sangat puas, dan juga sebaliknya. Hasil penelitian ini mendukung penelitian sebelumnya yang dilakukan oleh Laurent (2016) yang menunjukkan hasil bahwa e-service quality memberikan pengaruh yang positif terhadap kepuasan pelanggan.

\section{Pengaruh Positif Persepsi Harga terhadap Kepuasan Pelanggan}

Hasil uji $\mathrm{T}$ menunjukkan tingkat signifikansi 0,007 yang mana lebih kecil dari $0,05(0,007<0,05)$, serta koefisien regresi mempunyai nilai sebesar 0,153 . Maka penelitian ini berhasil membuktikan hipotesis kedua yang menyatakan bahwa terdapat pengaruh positif persepsi harga terhadap kepuasan pelanggan Gojek Yogyakarta.

Persepsi harga kerap kali digunakan pelanggan sebagai indikator nilai ketika persepsi harga tersebut dihubungkan dengan manfaat yang dirasakan atas suatu barang atau jasa. Pada persepsi harga tertentu apabila manfaat yang dirasakan meningkat, maka nilainya akan meningkat juga. Apabila nilai yang dirasakan pelanggan semakin tinggi, maka akan menciptakan kepuasan pelanggan yang maksimal (Tjiptono, 1999). Hasil penelitian ini mendukung penelitian sebelumnya yang dilakukan oleh Marta (2015) yang menunjukkan hasil bahwa persepsi harga berpengaruh positif terhadap kepuasan pelanggan.

\section{Pengaruh Positif Promosi Penjualan terhadap Kepuasan Pelanggan}

Hasil uji $\mathrm{T}$ menunjukkan tingkat signifikansi 0,000 yang mana lebih kecil dari $0,05(0,000<0,05)$, serta koefisien regresi mempunyai nilai positif sebesar 0,317. Maka penelitian ini berhasil membuktikan hipotesis ketiga yang menyatakan bahwa terdapat pengaruh positif promosi penjualan terhadap kepuasan pelanggan Gojek Yogyakarta.

Menurut Kotler (2007) promosi penjualan merupakan bahan inti dalam kampanye pemasaran yang terdiri dari short-term incentive dan dirancang untuk mendorong pembelian produk atau jasa tertentu secara lebih cepat atau lebih besar oleh konsumen atau perdagangan. Penjual menggunakan promosi jenis insentif untuk menarik pencoba baru, menghargai pelanggan setia, dan meningkatkan tingkat pembelian kembali pengguna yang jarang membeli. Promosi penjualan menawarkan insentif untuk membeli, sehingga manfaat yang ingin diberikan pemasar dapat diterima oleh pelanggan, oleh karena itu kepuasan pelanggan pun meningkat. Hasil penelitian ini mendukung penelitian sebelumnya yang dilakukan oleh Yulianto (2017) yang menunjukkan hasil bahwa promosi penjualan berpengaruh positif terhadap kepuasan konsumen.

\section{Pengaruh Positif Kepuasan Pelanggan terhadap Loyalitas Pelanggan}

Hasil uji $\mathrm{T}$ menunjukkan tingkat signifikansi 0,000 yang mana lebih kecil dari $0,05(0,000<0,05)$, serta koefisien regresi mempunyai nilai sebesar 0,304 . Maka penelitian ini berhasil membuktikan hipotesis keempat yang menyatakan bahwa terdapat pengaruh positif kepuasan pelanggan terhadap loyalitas pelanggan 
Gojek Yogyakarta.

Kepuasan pelanggan menjadi tujuan sekaligus sarana pemasaran bagi perusahaan, karena salah satu kunci untuk mempertahankan pelanggan adalah kepuasan pelanggan. Kepuasan pelanggan yang tinggi menimbulkan loyalitas pelanggan yang tinggi. Hal ini dikarenakan biasanya pelanggan yang sangat puas akan melakukan halhal yang menjadi indikator loyalitas pelanggan, seperti tetap setia untuk waktu yang lama, membeli lagi ketika perusahaan mengenalkan produk baru dan memperbarui produk lama, membicarakan hal baik tentang perusahaan kepada orang lain, tidak begitu memperhatikan merek lain serta tidak sensitif terhadap harga, bahkan menawarkan ide jasa atau produk baru kepada perusahaan. Hasil penelitian ini mendukung penelitian sebelumnya yang dilakukan oleh oleh Laurent (2016) yang menunjukkan hasil bahwa kepuasan pelanggan memberikan pengaruh yang positif terhadap loyalitas pelanggan.

\section{Pengaruh Positif E-Service Quality terhadap Loyalitas Pelanggan}

Hasil uji $\mathrm{T}$ menunjukkan tingkat signifikansi 0,000 yang mana lebih kecil dari $0,05(0,000<0,05)$, serta koefisien regresi mempunyai nilai sebesar 0,446 . Maka penelitian ini berhasil membuktikan hipotesis kelima yang menyatakan bahwa terdapat pengaruh positif e-service quality terhadap loyalitas pelanggan Gojek Yogyakarta.

Semakin efisien dan efektif suatu web atau aplikasi dalam memfasilitasi pelanggan, maka dapat dikatakan semakin baik kualitas pelayanannya. Ketika e-service quality baik, maka akan membuat pelanggan merasa puas karena kinerja web atau aplikasi sesuai dengan harapan mereka. Kepuasan pelanggan yang berkelanjutan dapat menciptakan loyalitas pelanggan yang akan sangat penting bagi kelangsungan hidup perusahaan. Hasil penelitian ini mendukung penelitian sebelumnya yang dilakukan oleh Laurent (2016) yang menunjukkan hasil bahwa e-service quality memberikan pengaruh yang positif terhadap loyalitas pelanggan.

\section{Pengaruh Positif Persepsi Harga terhadap Loyalitas Pelanggan}

Hasil uji $\mathrm{T}$ menunjukkan tingkat signifikansi 0,000 yang mana lebih kecil dari $0,05(0,000<0,05)$ dan koefisien regresi mempunyai nilai sebesar 0,241. Maka penelitian ini berhasil membuktikan hipotesis keenam yang menyatakan bahwa terdapat pengaruh positif persepsi harga terhadap loyalitas pelanggan Gojek Yogyakarta.

Persepsi harga merupakan faktor penting. Perusahaan harus selalu memonitor harga yang ditetapkan oleh para pesaing, agar harga yang ditentukan oleh perusahaan tersebut tidak terlalu tinggi atau sebaliknya. Dalam kenyatannya konsumen dalam menilai harga suatu produk sangat tergantung bukan hanya dari nilai nominal secara absolut tetapi melalui persepsi mereka pada harga (Nagle, 1995).

Secara spesifik, setiap konsumen menyadari hubungan yang relatif antara harga dan tingkat harapan mereka tentang produk yang akan dibeli. Selanjutnya, jumlah dari suatu harga yang ditawarkan dapat dibandingkan dengan pengalaman dan harapan konsumen sehingga harga yang ditawarkan dapat diterima atau dianggap sesuai dengan kualitas produk yang ditawarkan. Ketika pelanggan merasa harga yang diberikan oleh pemasar sesuai dengan nilai yang mereka terima, maka pelanggan akan merasa puas dan akhirnya akan menciptakan loyalitas pelanggan. Hasil penelitian ini mendukung penelitian sebelumnya yang dilakukan oleh Marta (2015) yang menunjukkan hasil bahwa persepsi harga berpengaruh positif terhadap loyalitas pelanggan. 


\section{Pengaruh Positif Promosi Penjualan} terhadap Loyalitas Pelanggan

Hasil uji $\mathrm{T}$ menunjukkan tingkat signifikansi 0,000 yang mana lebih kecil dari $0,05(0,000<0,05)$, serta koefisien regresi mempunyai nilai sebesar 0,503 . Maka penelitian ini berhasil membuktikan hipotesis ketujuh yang menyatakan bahwa terdapat pengaruh positif promosi penjualan terhadap loyalitas pelanggan Gojek Yogyakarta.

Promosi penjualan memiliki tujuan yang beragam, baik ditujukan bagi pelanggan baru maupun lama. Promosi penjualan juga dapat memiliki dampak jangka panjang dan dapat mempertahankan konsumen lama yaitu dengan cara meningkatkan tingkat pembelian kembali pengguna yang jarang membeli dan menghargai pelanggan setia. Insentif-insentif yang diberikan melalui promosi penjualan ini akan membuat pelanggan merasa dihargai dan lebih cepat untuk membeli, sehingga mereka akan mereka akan bertahan untuk menjadi pelanggan yang loyal. Hasil penelitian ini mendukung penelitian sebelumnya yang dilakukan oleh Yulianto (2017) yang menunjukkan hasil bahwa promosi penjualan berpengaruh positif terhadap loyalitas konsumen.

\section{Peran Mediasi Kepuasan Pelanggan} pada Pengaruh E-Service Quality, Persepsi Harga, dan Promosi Penjualan terhadap Loyalitas Pelanggan

Berdasarkan hasil boostrapping dengan Macro PROCESS terlihat pengaruh tidak langsung pengaruh e-service quality, persepsi harga, dan promosi penjualan terhadap loyalitas pelanggan melalui kepuasan pelanggan Gojek Yogyakarta. Hal ini dibuktikan dengan koefisien mediasi untuk variabel e-service quality bernilai sebesar 0,0442, koefisien mediasi untuk variabel persepsi harga bernilai sebesar 0,0404, dan koefisien mediasi untuk variabel promosi penjualan bernilai sebesar 0,0676 .

Hasil uji menggunakan metode bootstrapping Hayes untuk ketiga variabel juga menunjukkan rentang interval kepercayaan BootLLCI dan BootULCI tidak mencakup nilai nol. Maka, dapat disimpulkan estimasi signifikan dan terjadi efek mediasi. Dengan demikian penelitian ini berhasil membuktikan hipotesis kedelapan yang menyatakan bahwa terdapat e-service quality, persepsi harga, dan promosi penjualan terhadap loyalitas pelanggan melalui kepuasan pelanggan Gojek Yogyakarta.

E-service quality, persepsi harga, dan promosipenjualanmerupakansuatukondisi dinamis yang mampu memenuhi harapan pelanggan. E-service quality yang baik, persepsi harga yang tepat, dan promosi penjualan yang bagus dapat menjadi keunggulan bersaing bagi perusahaan jasa transportasi berbasis aplikasi online. Kosumen yang merasa puas secara tidak langsung akan menciptakan loyalitas. Dengan demikian dapat disimpulkan bahwa e-service quality, persepsi harga, dan promosi penjualan dapat menciptakan kepuasan pelanggan dan pada akhirnya akan menumbuhkan loyalitas pelanggan. Hasil penelitian ini mendukung penelitian sebelumnya yang dilakukan oleh Marta (2015) yang menunjukkan hasil bahwa terdapat pengaruh persepsi harga, kualitas pelayanan, dan suasana salon terhadap loyalitas pelanggan melalui kepuasan pelanggan sebagai variabel mediasi pada Flaurent Salon Yogyakarta.

\section{KESIMPULAN DAN SARAN}

\section{Kesimpulan}

Berdasarkan hasil penelitian di atas, maka dapat disimpulkan bahwa:

1. Hipotesis pertama yang mengatakan terdapat pengaruh positif e-service quality terhadap kepuasan pelanggan 
Peran Mediasi Kepuasan Pelanggan pada Pengaruh E-Service Quality, Persepsi Harga, dan Promosi Penjualan terhadap Loyalitas Pelanggan

Gojek Yogyakarta diterima. Hal ini dapat dibuktikan dengan tingkat signifikansi 0,012 lebih kecil dari 0,05, dan koefisien regresi mempunyai nilai sebesar 0,164 .

2. Hipotesis kedua yang mengatakan terdapat pengaruh positif persepsi harga terhadap kepuasan pelanggan Gojek Yogyakarta diterima. Hal ini dapat dibuktikan dengan tingkat signifikansi 0,007 lebih kecil dari 0,05 , dan koefisien regresi mempunyai nilai sebesar 0,153 .

3. Hipotesis ketiga yang mengatakan terdapat pengaruh positif promosi penjualan terhadap kepuasan pelanggan Gojek Yogyakarta diterima. Hal ini dapat dibuktikan dengan tingkat signifikansi 0,000 lebih kecil dari 0,05, dan koefisien regresi mempunyai nilai sebesar 0,317 .

4. Hipotesis keempat yang mengatakan terdapat pengaruh positif kepuasan pelanggan terhadap loyalitas pelanggan Gojek Yogyakarta diterima. Hal ini dibuktikan dengan nilai signifikansi 0,000 lebih kecil dari $0,05(0,000<0,05)$, dan koefisien regresi mempunyai nilai sebesar 0,304 .

5. Hipotesis kelima yang mengatakan terdapat pengaruh positif e-service quality terhadap loyalitas pelanggan Gojek Yogyakarta diterima. Hal ini dapat dibuktikan dengan tingkat signifikansi 0,000 lebih kecil dari $0,05(0,000<0,05)$, dan koefisien regresi mempunyai nilai sebesar 0,446.

6. Hipotesis keenam yang mengatakan terdapat pengaruh positif persepsi harga terhadap loyalitas pelanggan Gojek Yogyakarta diterima. Hal ini dapat dibuktikan dengan tingkat signifikansi 0,000 lebih kecil dari $0,05(0,000<0,05)$, dan koefisien regresi mempunyai nilai sebesar 0,241.

7. Hipotesis ketujuh yang mengatakan terdapat pengaruh positif promosi penjualan terhadap loyalitas pelanggan Gojek Yogyakarta diterima. Hal ini dapat dibuktikan dengan tingkat signifikansi
0,000 lebih kecil dari 0,05 $(0,000<0,05)$, dan koefisien regresi mempunyai nilai sebesar 0,503 .

8. Hipotesis kedelapan yang mengatakan terdapat pengaruh e-service quality, persepsi harga, dan promosi penjualan terhadap loyalitas pelanggan melalui kepuasan pelanggan sebagai variabel mediasi diterima. Hal ini dibuktikan dengan koefisien mediasi untuk variabel e-service quality bernilai 0,0442, koefisien mediasi untuk variabel persepsi harga bernilai 0,0404, dan koefisien mediasi untuk variabel promosi penjualan bernilai 0,0676 .

\section{Saran}

Saran yang dapat diberikan dalam penelitian ini di antaranya:

1. Bagi Pemasar Gojek Area Yogyakarta

Perusahaan Gojek sebaiknya meningkatkan kembali kinerja aplikasi, sehingga pelanggan lebih nyaman ketika akan memesan jasa Gojek melalui aplikasi. Gojek sebaiknya juga memperhatikan kembali strategi pemasaran yang digunakan, serta lebih waspada terhadap harga dan promosi penjualan yang diberikan pesaing, sehingga Gojek akan lebih mampu mengantisipasi beralihnya pelanggan yang sensitif terhadap harga dan mudah tergiur insentif.

2. Bagi Peneliti Selanjutnya

Bagi peneliti selanjutnya yang ingin meneliti atau melanjutkan penelitian ini, disarankan untuk meneruskan atau mengembangkan penelitian ini dengan mencari faktor lain yang dapat memengaruhi loyalitas pelanggan. Selain menggunakan teknik wawancara yang digunakan, bisa juga dikembangkan dengan teknik survei lapangan untuk mengamati kondisi di sekitarnya sehingga data yang diperoleh lebih lengkap dan dapat mengurangi data yang bersifat subyektif. 


\section{DAFTAR PUSTAKA}

Abadi, Hossein Rezaei Dolat. (2012). Analyze The Impact of Financial Variables on The Market Risk of Theran Stock Exchange Companies. Interdisciplinary Journal of Contemporary Research in Business, Vol.3 No.10 February 2012

Baron, R. M., \& Kenny, D. A. (1986). The Moderator-Mediator Variable Sistinction in Social Psychological Research: Conceptual, Strategic, and Statistical Considerations. Journal of Personality and Social Psychology, 51(6), 1173.

Ghozali, Imam. (2011). Aplikasi Analisis Multivariate dengan Program IBM SPSS 19. Semarang: Badan Penerbit Universitas Diponegoro.

Griffin, Jill. (2005). Customer Loyalty: Menumbuhkan dan Mempertahankan Kesetiaan Pelanggan. Alih bahasa Yati Sumiharti. Jakarta: Erlangga.

Hair, Jr. et al., (2010). Multivariate Data Analysis. United States: Pearson.

Hayes, A. F. (2013). Introduction to Mediation, Moderation, and Conditional Process Analysis. New York: Guilford.

Kertajaya, Hermawan. (2002). Mark Plus on Strategy: 12 Tahun Perjalanan Mark Plus \& Co Membangun Strategi Perusahaan. Jakarta: Gramedia Pustaka Utama.

Kotler, Philip. (2007). Manajemen Pemasaran. Jilid 2. Edisi 12. New Jersey: PT Indeks.

Kotler, Philip dan Amstrong Gary. (2008). Prinsip-Prinsip Pemasaran. Alih
Bahasa Bob Sabran M.M. Edisi Bahasa Indonesia. Jilid 1. Jakarta: Erlangga.

Laurent, Felicia. (2016). Pengaruh E-Service Quality terhadap Loyalitas Pelanggan Go-Jek melalui Kepuasan Pelanggan. Jurnal Program Manajemen Bisnis, Universitas Kristen Petra.

Lovelock, Christopher, Joachen Wirtz dan Jacky Mussry. (2010). Pemasaran Jasa: Manusia, Teknologi, Strategi. Perspektif Indonesia. Jakarta: Erlangga.

Martha, Enggar Puspita. (2015). Pengaruh Persepsi Harga, Kualitas Pelayanan, dan Suasana Salon terhadap Loyalitas Pelanggan melalui Kepuasan Pelanggan (Studi pada Pelanggan Flaurent Salon Yogyakarta). Tesis. Universitas Negeri Yogyakarta.

Nagle, Thomas T. and Reed K. Holden. (1995). The Strategy and Tactics of Pricing, A Guide to Profitable Decision Making. Edisi 2. New Jersey: Prentice-Hall, Inc.

Peter, J. Paul \& Jerry C. Olson. (1999). Consumer Behavior: Perilaku Konsumen dan Strategi Pemasaran. Jilid Kedua, Edisi Keempat. Terjemahan Damos Sihombing dan Peter Remy Yossi Pasla. Jakarta: Erlangga.

Rodgers, W., Negash, S. \& Suk, K. (2005). The Moderating Effect of Online Experience on the Antecedents and Consequences of Online Satisfaction. Journal of Psychology and Marketing, 22(4), 313-331.

Sawitri, Ni Putu., Kerti Yasa Ni Nyoman., dan Jawas Abbdullah. (2013). Pengaruh Kualitas Pelayanan terhadap Kepuasan dan Loyalitas Pelanggan Tegal Sari Accommodation di Ubud. Jurnal 
Peran Mediasi Kepuasan Pelanggan pada Pengaruh E-Service Quality, Persepsi Harga, dan Promosi Penjualan terhadap Loyalitas Pelanggan

Manajemen, Strategi Bisnis, dan Kewirausahaan, 7 (1) pp 40- 47

Schiffman, L., \& Kanuk, L. (2011). Perilaku Konsumen. New Jersey: Prentice Hall.

Sugiyono.(2010). Metode Penelitian Pendidikan Pendekatan Kuantitatif, Kualitatif, dan $R \& D$. Bandung: Alfabeta.

Sundaram, Vijayanand, dkk. (2017). Impact of E-Service Quality on Customer Satisfaction and Loyalty. Empirical Study in India Online Business.

Tjiptono, Fandy. (1999). Strategi Pemasaran. Yogyakarta: ANDI
Yulianto, Indra, dkk. (2017). Pengaruh Promosi Penjualan, Harga, dan Kualitas Pelayanan terhadap Kepuasan Konsumen dan Loyalitas Konsumen (Studi Kasus Counter Handphone di Shiba Communication), Journal of Management, Vol.3, No.3.

Zeithaml, V., Parasuraman, A. and Malhotra, A. (2002). Service Quality Delivery Through Websites: A Critical Review of Extant Knowledge. Journal of the Academy of Marketing Science, Vol. 30 No. 4, pp. 362-75. 